\title{
The Role of Platforms and Platform Thinking in Open Innovation Networks
}

\author{
Ahmad Ghazawneh \\ Jönköping International Business School \\ ahmad.ghazawneh@ihh.hj.se
}

\begin{abstract}
Firms that identify themselves as innovative have to constantly and continuously generate a stream of value-rich products and services, and improve them by time targeting growth markets and finding new ones for their core technologies. To achieve this, they start to open their innovation practices by adopting the open innovation paradigm, giving the opportunity to actors to engage in innovation networks. This paper discusses the supportive roles of platforms and platform thinking concepts in the practices that take place in innovation networks based on the dimensions of translations in such networks. The paper illustrates two practical examples of such roles, exemplifying how platform adopting can enhance and support the innovative practices.
\end{abstract}

\section{Introduction}

The interaction between business and technologyfocused innovation is becoming diffused in today's changeable and erratic global economy which impacts the world everyday. Consequently, this affects hundreds, perhaps thousands of firms motivating them to bring new products and services to markets in order to satisfy the needs of customers athirst for new technologies and innovations. This creates strong competition on a global scope, where firms strive to remain on the scene by increasing customers' satisfaction and trying hard to lower internal costs [2], meet diverse customers' requirements and at the same time maintain economy of scale and scope within processes of development [3]. Meanwhile, firms' drive to maximize profits by setting competitive products in many diverse market segments and development and production time and costs must be maintained [4].

For firms in different industries, especially in the high-tech sector, changing their centralized business approach is fundamental to remain highly competitive. This change mainly follows the "open innovation" paradigm while adopting the remedy approach of "platforms". In so doing, the firms rely on external sources for innovations in industries, products and services, enabling the same sources to innovate upon their evolving system in an interdependent way [1]. Hence, the greater the number of actors taking place in those innovation networks, the more innovation will be driven to the development of products and services. These actors and their innovations will be formulated in a manner that will constitute a strategic advantage for the firms by helping them better understand their users' needs. This helps the firms reduce time, exert less efforts and lower costs in a more effective way than if they had to do the job themselves [5], a successful strategy that matches between the fulfillment of market demand and the creation of firms' internal benefits [6].

There are various examples of platforms that have attracted rapidly growing innovation networks consisting of a variety of stakeholders such as service providers, technology vendors, customers, developers, competitors, scientific communities and other interested groups. Such examples include the "platforms" adopted by firms like Intel, Microsoft, Cisco [1], Google, Amazon, Apple, and eBay [8] and others. Yet, there are numerous examples of platforms' initiatives that have not attracted similar growth and some research indicates that they have at times not been helpful or advantageous [7]. It has been well recognized in academia as well as in practice that there is rationality in developing and adopting "platforms" in order to achieve product variety and maintain economies of scale $[6,9,10,11]$. Those "platforms" play considerable roles in helping firms look for continuous product development in finding new competitive capabilities and shaping their development and operations strategies [12]. This is well understood by firms that identify themselves as innovative, where they have to constantly and continuously generate a stream of value-rich products and services, and improve them by time targeting growth markets and finding new ones for their core technologies [13].

Previous research studying the "open innovation" paradigm focuses primarily on exploring the open innovation practices and how they can enhance the firms' internal R\&Ds by harnessing external ideas and 
stimulating the development of products and services (see e.g., [36, 37, 38, 39]). Some scholars have explored those practices in connection with particular fields, such as Mobile Telephony [40], Open Source $[41,42]$ and Food Industry [43, 44]. However, there is a lack of studies on how such practices can be supported. The aim of this paper is to discuss the role of platforms and "platform thinking" in open innovation networks by which different stakeholders commit to platforms and thereby contribute to building strong and competitive innovation networks. More precisely, the paper discusses the supportive roles of different types of platforms in the practices that take place in innovation networks based on the dimensions of translations in such networks.

The paper is structured as follows. I start by introducing the notion of platforms and "platform thinking", followed by a description of the five main types of platforms. Then the benefits and distinctiveness advantages of adopting the "platform thinking" are illustrated. After that the open innovation paradigm is introduced, and its objectives are discussed in relation to the "platform thinking" offerings. The paper then introduces the innovation network and the cognitive and social translations that take place and form such networks. In the discussion part, the role and implications of platforms in open innovation networks are discussed and thereafter the interplay between product platform and open innovation networks is analyzed based on the two practical examples. The paper ends with some concluding remarks.

\section{The notion of platforms and "platform thinking"}

According to Muffatto and Roveda [12, 14] the "platforms" concept is an issue that is still being discussed in the literature, where it is possible to find out "narrow definitions" that sound extremely technical and seldom are product-industry based, (see e.g., $[15,16,17])$, as well as "broad definitions" that aim at embracing various industries and innovation processes, which result in highly generic and abstract ones (see e.g., $[18,19,20,13])$. Thus, and in order to capture the platform scope fruitfully, the discussion ought to be based on the "platform thinking" concept that is seen as "the process of identifying and exploiting the shared logic and structure in a firm's activities and offerings to achieve leveraged growth and variety" [22]. This concept which can be applied in a firm's products, development processes, brands, targets and customers appears to be a successful strategy to achieve leveraged high variety of products and services with efficient uses of resources $[9,20,22$,
46, 47]. And it constitutes of five main types of platforms:

\subsection{Product platform}

According to Halman et al. [45] one of the possibilities to build a platform is to define it by means of the product architecture, where numerous available definitions for the term, that is adopted in different contexts and scopes in such product development environments, can be found (see e.g., $[13,17,20,21$, 23, 24, 25]). According to Meyer [13], a product platform is " $a$ set of subsystems and interfaces that form a common structure from which a stream of derivative products can be efficiently developed and produced". Corso et al. [18] has a similar perspective, defining the platform as "set of norms and standards integrating subsystems that evolve over time, under some constraints, that form a sort of technological trajectory". While several definitions like the prementioned ones do not bring up the technology roles explicitly, others such as McGrath [21] emphasize the mainly technology-related role and define the product platform primarily as "the set of architectural rules and technology elements that enable multiple product offerings and define the basic value proposition, competitive differentiation, capabilities, cost structure, and life cycle of these offerings". Some others, such as Robertson and Ulrich [20] hold a holistic view, and define the product platform as "the collection of assets that are shared by a set of products".

Based on the literature review it is clear that the commonality of the product platform is based on its "assets", which are divided into four categories [20]:

1. Components: the part designs of a product, the fixtures and tools needed to make them, the circuit designs, and the programs burned into programmable chips or stored on disks.

2. Processes: the equipment used to make components and the associated production and development process and supply chain.

3. Knowledge: design know-how, technology applications and limitations, production techniques, mathematical models and testing methods.

4. People and relationships: teams, relationships among team members, relationships between the team and the larger organization, and relationships with a network of suppliers.

And as these shared assets constitute the product platform, they not only consider the physical and 
technical entities, but also include human, knowledge, design and functional resources. And this has an effect upon the platform's scope, making it more comprehensive and integrated. Thus, the product platform concept to be primarily defined as:

A set of subsystems, interfaces, standards and technology elements forming a common and evolving structure from which a mass of derivative products or services can be innovated, developed and deployed. It constitutes of four main assets: components, processes, knowledge and people that can be set in various development environments to help firms achieve a competitive advantage.

This implies that there are three main parts of product platforms adopted in different development environment contexts : (1) the core products or services, (2) the derivative products or services, and (3) the four main assets. For firms adopting and implementing platforms, it is very significant to identify and assess these three main parts carefully and well in respect to the values that they stand for, their offerings, their employed technologies, and the stakeholders that they control and target [22]. Examples of product platforms are the Windows/Intel computer platform [22], Amazon e-commerce platform [8], Cisco platform [1] and most recently the platform of Apple's iPhone [32].

\subsection{Process platform}

Process platform refers to the specific arrangements of the development and production systems to produce the desired variety of products and services easily [45]. It can be applied to the different processes involved in the design, development, and distribution of firm's offerings [22]. Sawhney [22] refers in this respect to Titan's ${ }^{1}$ three distinct process platforms: (1) mass production process, (2) the runner process, and (3) the job-shop process, where the company allocates products to the appropriate process platform based on the volume and flexibility of development and manufacturing. Another example of a process platform is the one adopted by Sony and based on (1) flexibility, (2) small-lot production, and (3) ease of model change in mind [45].

\subsection{Customer platform}

Refers to the customers' segment that is chosen by the

\footnotetext{
${ }^{1}$ Titan Industries Limited: an international watch manufacturer based in India [22].
}

firm as a standpoint of entry to a new market. This segment is expected to be compatible with the firm's offerings and serves as a basis for both expansion and leveraged growth into related segments and application markets [22, 45]. Sawhney [22] refers in this respect to Intuit in the financial software market, since it targets home users as an initial customer platform for their personal financial management software. The firm later, expanded the offerings by related applications for the same customer segment that includes tax planning and legal software and others as well. Intuit also targeted related segments, by creating similar offerings that includes financial, payroll and invoicing management products for small business. Other products and services attributable to the firm's success include the choice of customer platform includes: Apple Macintosh, Lotus Notes and US Robotics Pilot organizer [22].

\subsection{Brand platform}

Brand platform is considered as the core of a firm's specific brand system. It can be the corporate brand (e.g., Microsoft, Apple, General Motors, Google), or the product brand (e.g. xBox, iPhone, Chevrolet, Gmail). It conveys the central value proposition and is a key motivator for related decisions. From this brand platform corporate brands, product brands and all subbrands are managed not as individual brands but as a system to minimize brand identity overlap and to achieve coherence and clarity of positioning among the products and services. It also enables the firm to leverage its brand equity across multiple offerings [22, 45].

\subsection{Global platform}

The global platform is the core standardized offering of a product or a service globally. It manages the contradiction between standardization and adaptation $[22,45]$. For example, developing an Enterprise Resource Planning (ERP) system for the global market is a challenge that needs a global platform. The global platform details the product or service aspects that can be standardized and those aspects that should be adapted to a country's or a stakeholder's specific conditions, requirements and preferences. Sawhney [22] illustrates an example of a global platform from the automobile industry, namely the one designed by Honda for its 1998 Accord, which can be used to produce the company's American, Japanese and European versions of the model. 


\section{Benefits of "platform thinking"}

There are various distinctiveness advantages for firms adopting the concept of "platform thinking" in the development processes and practices of their products and services. And most importantly, adopting the "platform thinking" concept appears to be a very successful strategy to create a variety of products and services with efficient uses of resources $[9,20,22,46$, 47] to help firms to compete more effectively by coping with customers' needs athirst for new technologies and innovations overtime. The benefits of "platform thinking" $\mathrm{s}$ is seen as a concept that simultaneously improves [22]:

- Speed: The development time for products and services based and on a "platform" can be reduced dramatically by the reuse of associated platform's technology and services. The platform will be able to receive numerous varieties of products and services developed by suppliers working on them.

- Cost: Platform thinking plays a significant role in reducing the cost of the design, operating, marketing and development of new products. Sharing core design components reduces design costs. Sharing the platform core brand and common customer bases increases customer loyalty and reduces the cost of marketing, product brand building and customer acquisition costs. Sharing development and operation processes among stakeholders and suppliers reduces development and labor costs.

- Design quality: The design quality of products can be improved by the use of common underlying platform standards, technologies, and components which are generally debugged, tested and qualityassured. In addition, improvements of performance or any other platform aspects will automatically affect all derivative products and services created upon the platform.

- Coherence: Products and services offered based on platforms have the ability to be extended more logically and coherently. They also stand in a coherent manner beside others in markets.

- Referenceability: Products and services developed on platforms usually have the ability to be marketed to a core customer base or customers logically related to the core customer base. The value of the core product of the platform and the relatedness among the core product, the derivative products, the users and the developers/content generators have results in a robust brand promotion.

- Option Value: Firms' investments in platforms and core technologies represent a set of "call options" that a firm can use to exercise in other businesses and lines.

\section{Open innovation}

Innovation is seen as the art of developing a product, service or process based on new created ideas [48] that are new to the adopting unit [49]. For decades, companies were able to innovate based on their internal R\&Ds, collaboration, operations and development processes and practices. Those companies mainly follow the "closed innovation" model and its principles in their development and production practices. In this closed innovation model, companies generate, develop and commercialize their own ideas and solutions, and their self-reliance on their internal R\&Ds, collaboration, resources and operations dominate their practices [28]. However, the developments of new technologies, the new global market and the new scientific initiatives go beyond the capabilities of today's companies working individually and relying on their internal sources and capabilities [27]. And it becomes essential for those companies to shift from their own closed model to a more open one by integrating external ideas, solutions, resources and capabilities into their developments and other related practices to help them achieve greater return and stay competitive.

In this new model of innovation, referred to as Open Innovation, a company combines both its own internal ideas and solutions as well as external ones coming from individuals, groups or companies, and commercializes them to market by external or internal paths as well [28, 29]. it is simply "the use of purposive inflows and outflows of knowledge to accelerate internal innovation, and expand the markets for external use on innovation, respectively" [29]. This exemplifies the suggestion that valuable and feasible ideas can not only be initiated and come from inside the company but also from outside sources, applied on internal and external paths to market.

\subsection{Open innovation objectives and "platform thinking" offerings}

Adopting the open innovation paradigm, implementing its practices and following its principles will, among other things, influence the firm and its business model by speeding up its products and 
services time to market, lower the R\&D and operating costs, support the internal $\mathrm{R} \& \mathrm{D}$ with virtual communities, find solutions to complex problems, understand the market and stakeholders' needs better, provide access to new markets, profit from "unprofitable IPs" by licensing or selling them to external partners and turn others' IPs profitable [28, $29,30]$. A thorough look at the objectives of the open innovation paradigm and the offerings of "platform thinking" leads to simultaneous improvements in speed, cost, design quality, referenceability, coherence and option value with the "platform thinking" offerings [22] well-suiting and efficiently incorporated with the objectives of open innovation and its anticipated effects on firms and stakeholders.

Table 1. The objectives of open innovation and the associated "platform thinking" offerings.

\begin{tabular}{|l|l|l|}
\hline & $\begin{array}{l}\text { Open Innovation } \\
\text { Objectives }\end{array}$ & $\begin{array}{l}\text { Platform Thinking } \\
\text { Offerings }\end{array}$ \\
\hline Speed & $\begin{array}{l}\text { Speeds up products } \\
\text { and services time to } \\
\text { market. }\end{array}$ & $\begin{array}{l}\text { Development times } \\
\text { can be reduced by the } \\
\text { use of associated } \\
\text { technologies of the } \\
\text { platforms. }\end{array}$ \\
\hline Cost & $\begin{array}{l}\text { Lower s the R\&D and } \\
\text { operating costs. }\end{array}$ & $\begin{array}{l}\text { Sharing platforms core } \\
\text { components reduces } \\
\text { the cost of } \\
\text { developments, designs, } \\
\text { operating, etc. }\end{array}$ \\
\hline Design Quality & $\begin{array}{l}\text { Supports external } \\
\text { ideas, solutions and } \\
\text { knowledge. }\end{array}$ & $\begin{array}{l}\text { Can be improved by } \\
\text { the use of common } \\
\text { underlying platform's } \\
\text { technologies, standards } \\
\text { and components. }\end{array}$ \\
\hline Referenceability & $\begin{array}{l}\text { Uses internal and } \\
\text { external paths for } \\
\text { marketing and } \\
\text { commercialization }\end{array}$ & $\begin{array}{l}\text { Platforms help in } \\
\text { marketing products } \\
\text { and services to core } \\
\text { customers'base. }\end{array}$ \\
\hline Coherence & $\begin{array}{l}\text { Uses of others' IPs } \\
\text { Intellectual Properties } \\
\text { which can extend the } \\
\text { products and services. }\end{array}$ & $\begin{array}{l}\text { Products and services } \\
\text { can be extended more } \\
\text { logically and coherent } \\
\text {-ly. }\end{array}$ \\
\hline Option Value \\
$\begin{array}{l}\text { Profiting from } \\
\text { lunprofitable IPs' by } \\
\text { licensing or selling } \\
\text { them to external } \\
\text { partners }\end{array}$ & $\begin{array}{l}\text { Platforms represent a } \\
\text { set of "call options" } \\
\text { that a firm can use to } \\
\text { exercise in other } \\
\text { businesses and lines }\end{array}$ \\
\hline
\end{tabular}

\subsection{Innovation networks}

Innovation networks are seen as socio-technical networks of organizations that enable innovation [35] by producing and consuming necessary knowledge through various connected actors and ICT tools. These networks are influenced by the continuing development of digital technologies, services and processes, as they enable actors to connect to these networks and carry out innovation in various forms. These networks are also influenced by "platform thinking" as a recipe for establishing successful networks based on the multidimensional aspects that such "thinking" offers, which not only assist firms to achieve high variety and growth of products and services, but also act as an environment for establishing ideas, solutions and knowledge which feed the innovation networks, and connect the network members, their activities, resources, knowledge and capabilities which support its socio-technical nature. Innovation that takes place in such networks is conceptualized as a "series of translations between ideas, representations and material realization of the ideas (either in the form of physical products or services), mediated through technology artifacts" and this innovation is simultaneously cognitive and social, forming the dimensions of translations in innovation networks [35].

1. Cognitive translations: Cognitive translation involves the creation of new ideas and solutions which are to be translated through various representations before becoming new products and services $[35,50]$, and during this process "innovators deploy various tools and artifacts that assist in the translation as to make their own perspective known to others" [35]. This dimension of translation does not essentially take a linear progress but it may perhaps become iterative, as it is the case in most cases of the cognitive translation found to be progressing in a sense of moving forward while innovators deployed assistance tools and artifacts to make their perspectives known to others [35].

2. Social translations: Social translations usually take place at the "boundaries of communities where individual actors negotiate and mutually adjust to other's perspectives", a concept essential in shaping the innovation. This type of translation can be thought of as a "series of back-and forth movements of influence among actors" [35] which their relationships are mediated by mainly digital artifacts where different types of connections takes place between them within these communities. Connection types are complementary, dialectical and dialogical [35].

Table 2. Connection types among individuals in innovation networks.

\begin{tabular}{|l|l|}
\hline $\begin{array}{l}\text { Connection } \\
\text { Type }\end{array}$ & Description \\
\hline Complementary & $\begin{array}{l}\text { Innovation is created by combining two } \\
\text { previously unconnected communities. }\end{array}$ \\
\hline Dialectical & $\begin{array}{l}\text { Innovation occurs through an unlikely } \\
\text { link of two opposing perspectives, and the } \\
\text { innovation is likely to be radical and } \\
\text { discontinuous. }\end{array}$ \\
\hline Dialogical & $\begin{array}{l}\text { Innovation is created in an environment } \\
\text { where there is a never-ending tension }\end{array}$ \\
\hline
\end{tabular}


between individuals where each side assumes that the other exists and the interplay is constant.

\section{Practical examples of product platforms}

\subsection{The iPhone's product platform}

The iPhone is considered one of the projects adopting the open innovation paradigm since it does not only depend on internal but external and distributed sources for the developments of its applications and services. Almost any person, company, or government can all act as ideas' initiators and developers of native applications that can work in the iPhone's environment $[32,34]$. The adoption of this open innovation model is mainly fulfilled by the implementation of a product platform that enables almost anyone to innovate upon its evolving system in an interdependent way.

The core product of this platform is the iPhone device and the derivative products and services are the applications of different kinds that can run on the core product and can be developed by almost any person, organization or government. iPhone has the platform's four main "assets" which as outlined above are divided into four categories [20]:

1. Components: iPhone's product platform mainly constitutes the following components: (a) the Software Development Kit (SDK) that includes tools for developing and debugging application code and designing an application user interface, (b) the Application Programming Interfaces (APIs), and (c) the Operating System (OS) [32].

2. Processes: the associated production, development and supply chain processes and practices of the iPhone's product platform starts by initiating an application's idea or solution by any user, who then uses the platform's SDK and APIs components to implement the idea. This is followed by submitting the developed application to the platform's associated personnel to be reviewed. Then if the application is accepted, it will be soon available for purchase and download by iPhone's users through the AppStore ${ }^{2}$ service. If the application is rejected, the developer may still redesign and modify the application and reenter the process [32].

3. Knowledge: iPhone's Development Center ${ }^{3}$ provides developers with the design and

\footnotetext{
${ }^{2}$ http://www.apple.com/iphone/apps-for-iphone/

${ }^{3} \mathrm{http}: / /$ developer.apple.com/iphone/
}

development know-how and other technical information that can help developing with the latest technologies in iPhone. The center provides application programming and development guides, human interface guidelines, documents and videos, and discussion forums as an environment to discuss technical aspects of developing software for iPhone [32].

4. People and relationships: In order for Apple, the proprietor of the iPhone's product platform, to create a close relationships with the developers, it has initiated the Apple Worldwide Developers Conference (WWDC) where developers and IT professionals innovating with the platform can meet, socialize, hear about new ideas and methods. The conference includes technical sessions, handson labs, peers-connection sessions and other special events. Apple usually sends about 1,000 of its engineers to meet thousands of developers coming from all over the world [32].

\subsection{Facebook's product platform}

Facebook, the popular online social networking site has also adopted a product platform that is based on the open innovation paradigm. This product platform allows anyone with the appropriate skills to build rich applications that run on Facebook and let users interact with each others [51]. The core product of this platform is the Facebook website and the derivative products and services are all rich applications which are developed internally by Facebook's development team or externally by almost any user. And as in the iPhone's case, Facebook's product platform consists of the four main "assets":

1. Components: Facebook's product platform comprises a number of core components including: (a) the Application Programming Interfaces (APIs), (b) FBML, Facebook Markup Language, that allows developers to integrate their applications into Facebook, (c) XFBML which is an extension to FBML and lets developers incorporate FBML into Facebook Connect ${ }^{4}$ sites, (d) FQL, the Facebook Query Language, and (e) FBJS, the method that lets developers incorporate JavaScript into their application. This is in addition to various client libraries, such as Perl, C++, and .Net [51].

\footnotetext{
${ }^{4}$ Facebook Connect is: the next evolution of Facebook Platform enabling developers to integrate the power of Facebook Platform into their own site, desktop application, iPhone app, and beyond [51].
} 
2. Processes: The process taking place in Facebook's product platform starts by initiating an application idea that meets Facebook's principles of having a meaningful, trustworthy and well-designed application based on the idea of making the web more social for users accompanied by the use of the rest of the platforms' assets. However, and unlike iPhone's product platform, Facebook does not apply a mandatory verification of each submitted application, but it keeps this as an optional choice for developers to reassure the users that their application provides a good experience and make them feel more confident about its use [51].

3. Knowledge: Facebook provides developers with knowledge resources of all kind that can help them in their collaboration and development practices within the product platform, including documentations, tools, discussion forums and wikis. In addition, Facebook supports their knowledge asset with multimedia based guidelines and practical examples that help users in all levels to handle their collaborative development practices. Facebook also uses a dedicated product platform blog to keep developers updated about announcements and related news [51].

4. People and relationships: Facebook has a very strict relationship with its developers through the regular initiation of industry events, developer conferences, developer programs and roundtables which create opportunities for developers to have dialogues with the platform team regarding business and technical aspects of the product platform. One of the most recognized events of the product platform is the Garage program that started in 2007 in San Francisco and has been followed by several events taking place in different countries all over the world [51].

\section{Discussion}

\subsection{The role and implications of platforms in open innovation networks}

As cognitive and social translations are tightly intertwined in the practice and "the cognitive translation constrains and is constrained by the social translation" [35], the role of various platforms emerges in both translations in facilitating the representations and translation practices, and all platforms together act as an environment for innovation networks and various associated practices whether theoretical or practical.

\section{Cognitive translations: role and implications}

1. Product platform role: the product platform acts as an environment for creation and translation of new ideas that lead to innovation. Two of the four main assets of the product platform emerge in the cognitive translation side of the innovation network. Firstly, the "processes asset" that identifies the associated ideas' creation and development processes, which can work as a roadmap for actors to follow the actions that are required for having a successful contribution of a new idea that leads to the innovation of a new product and service. Secondly, the "knowledge asset" that identities the design know-how, technology applications and limitations, production techniques, mathematical models and testing methods to be applied in the development of ideas and solutions.

2. Process platform role: this role enhances the translation by providing specific arrangements of the development processes to easily produce the desired variety of products and services. This is to be applied in the design, development, and distribution of the offerings afterwards. A case in point is to categorize the new initiated ideas based on desired outcomes of products and services, and arrange their associated design, development and distribution processes based on this categorization.

3. Brand platform role: this inspires innovators and collaborators for strategies to build and enhance the core branding system of the anticipated products and services that will be created after walking through the translation processes.

\section{Social translations: role and implications}

1. Product platform role: the product platform acts as an environment for collaboration to connect individuals (actors) regardless of the connection type that is taking place. The remaining two assets of the product platform emerge in the social translation side of innovation networks. Firstly, the "component" asset that includes the ICT and digital artifacts mainly mediates the relationships between actors in the networks and facilitates and strengthens the connections. This asset also provides actors with the appropriate tools and programs to develop ideas and materialize them as new products and services Secondly, "people and relationships" asset provides the innovation networks of an overview and plans on teaming up actors, relationships among team members, relationships between the team and the larger organization, and relationships with network of suppliers. 
2. Customer platform role: As innovation and mass collaboration shift customers' role from being consumers of products and services, and stand-by users to becoming knowledge and content producers, and having more active roles in the innovation networks [8], the customer platform here applies on actors taking place in innovation networks, and its role emerges in identifying actors' segment that is chosen by the firm as a standpoint of entry to open innovation and its networks. This platform is expected to enhance the social translations by choosing a segment that is compatible with various connection types and serves as a basis of both expansion and leveraged growth into related networks. Customer platform can be extended to categorize actors within innovation networks and allocate them in appropriate innovation segments based on their knowledge, purposes and qualifications.

3. Global platform role: The role of the global platform mainly emerges before, during and after innovation practices take place where it is very significant to find a core standardized offering of new ideas and innovations among the networks which will then manage the anticipated contradiction between standardization and adaptation of products and services.

\subsection{The interplay between product platform and open innovation networks}

As described in $\S 6.1 .1$ and $\$ 6.1 .2$ product platform constitutes physical and technical entities, human, knowledge, design and functional parts in the "platform thinking", and as its four main assets have roles in the entire innovation network and in its both translation processes. Hence, this paper attempts to illustrate two practical examples regarding the adoption of this type of platform in two different core products. Both examples confirm that implementing the open innovation paradigm is facilitated by the adoption of the entire product platform and its four entities. The product platform in those two examples takes its main acting roles as an environment for creation and translation of new ideas that lead to innovation, and facilitating collaboration practices and connecting developers.

In the social translations of the two examples it is clearly indicated how the "Component" asset of the product platform of both the iPhone and Facebook appropriately provides developers with the required tools and programs to facilitate the development of applications and materialize them as new finished services that can be used by the users of the core product of the open innovation network. These tools are seen as the raw material that helps building core products that can vary from one product platform to another .Next is the "People and Relationships" asset that appears to have major roles in the social translations part of the innovation networks of both examples. This asset connects developers in a strict relationship with the proprietors of both platforms and associated staff. It is clear that Facebook and Apple have translated these relationships practically in various forms, such as, conferences, events, roundtables, reflecting their deep understandings of the value of engaged developers in connection with essence aspects of their product platform. This kind of engagement is essential for the innovation network and especially when there is no direct income "revenues" for the collaborated communities.

In the cognitive translations of both examples the other two assets of the product platform take place. The Knowledge asset that helps the proprietors of the platforms to provide all required knowledge to developers facilitates their development practices within the innovation networks. The product platforms of the iPhone and Facebook invest too much efforts in supplying developers with all documentations, guidelines, discussion tools and forums that help them as they translate their ideas into workable applications that feed the innovation network. This "asset" in the two illustrated examples usually helps junior and senior developers to understand the development environment and obtain answers of basic and complex problems that may occur while innovating. The role of the "processes" asset also emerges as a roadmap for developers that can assist them making a successful contribution to the innovation network by practically validating the contribution within the network itself and making it available for end-users. The product platforms of the iPhone and Facebook have two different "processes" assets that reflect two different methods of dealing with innovations within open innovation networks.

Basic information and statistics, see table 3, show significant growth in the number of developers and applications that are initiated and developed in order to satisfy the users who are athirst for new technologies and innovations. Both "product platforms" in a short period of time manage to attract thousands of developers with innovative ideas that are translated into useful services to feed the innovation network. This acts as a practical evidence of the value of adopting such a "product platform" where open innovation stands as the base environment and where firms believe in the process of driving innovations to their industries, products and services from external sources, making it possible to those sources to innovate upon their evolving system in an interdependent way to attract users to their core products and services. 
Table 3. Basic information and statistics for the product platforms of the iPhone and Facebook [32,51].

\begin{tabular}{|l|l|l|}
\hline & iPhone PP* & Facebook PP* \\
\hline Launching Date & July 2008 & Summer 2007 \\
\hline PP Core product & Mobile Device & Website \\
\hline PP Status & Active & Active \\
\hline No. of Developers & 250,000 & $1,000,000$ \\
\hline No. of Applications & 35,000 & 350,000 \\
\hline No. of Users & 30 million & 250 million \\
\hline
\end{tabular}

*PP: Product Platform

\section{Conclusion}

As open innovation paradigm is increasingly adopted and as practices within its innovation networks are applied in firms that identify themselves as innovative, where they have to constantly and continuously generate a stream of value-rich products and services, and improve them by time targeting growth markets and finding new ones for their core technologies, it becomes critical to examine approaches that play significant roles in such innovation paradigm and its related networks where practices can be supported and enhanced. This paper has examined the roles of "platform thinking" concept in open innovation networks and used two practical example to support the discussion. Future empirical work is needed to examine the roles of the various types of platforms and how firms can adopt them in appropriate ways.

\section{References}

[1] Gawer, A. and Cusumano, M.A., (2002). Platform leadership: how Intel, Microsoft, and Cisco drive industry innovation. Harvard Business School Press, Boston.

[2] Pine, B.J., (1993). Mass customization: the new frontier in business competition. Harvard Business School Press, Boston.

[3] Huang, G.Q., Simpson, T.W. and Pine, II, B.J. (2005). The power of product platforms in mass customization. Int. J. Mass Customisation, Vol. 1, No. 1, pp.1-13.

[4] de Weck, O.L., Suh, E.S., and Chang, D., (2003). Product Family and Platform Portfolio Optimization. Proceedings of 2003 ASME Design Engineering Technical Conferences, Chicago, Illinois USA.

[5] von Hippel, E. and Katz, R. (2002). Shifting innovation to users via toolkits. Management Science, 48(1), 821833.

[6] Sanderson, S.W. and Uzumeri, M., (1997). Managing product families. Irwin Professional Pub., Chicago.

[7] Hauser, J.R., (2002). Metrics thermostat *. Journal of Product Innovation Management, Vol. 18, pp. 134-153.
[8] Tapscott D. and Williams A.D (2006). Wikinomics: How Mass Collaboration Changes Everything. New York (N.Y.): Portfolio.

[9] Meyer, M.H. and Lehnerd, A.P., (1997). The power of product platforms: building value and cost leadership. Free Press, New York.

[10] Da Silveria, G., Borenstein, D., Fogliatto, F.S. (2001). Mass Customization: Literature review and research directions. International Journal of Production Economies, 72(1): 1-13.

[11] Simpson, T.W. (2004). Product platform design and customization: Status and promise. AIEDAM, Special Issue on Platform Product Development for Mass Customization, 18(2).

[12] Muffatto, M. and Roveda, M., (2002). Product architecture and platforms: a conceptual framework. International Journal of Technology Management, Vol. 24, pp. 1- 16

[13] Meyer, M.H. (1997). Revitalize your product lines through continuous platform renewal. Research Technology Management, March-April.

[14] Muffatto, M. and Roveda, M., (2000). Developing Product Platforms: Analysis of the Development Process. Technovation, Vol. 20, pp. 617-630.

[15] Meyer, M.H. and Utterback, J.M. (1993). The product family and the dynamics of core capability. Sloan Management Review, Spring.

[16] MacDuffie, J.P., Sethuraman, K. and Fisher, M. (1996). Product variety and manufacturing performance: evidence from the International Automotive Assembly Plant Study. Management Science, Vol. 42, No. 3, March, pp.350-369.

[17] Wilhelm, B. (1997). Platform and modular concepts at Volkswagen - their effects on the assembly process, in K. Shimokawa, U. Jurgens and T. Fujimoto (Eds.), Transforming Auto Assembly, Springer-Verlag, Berlin, pp.146-156.

[18] Corso, M., Muffatto, M. and Verganti, R. (1996). Multiproduct Innovation: emerging policies in automotive, motorcycle and earthmoving machinery industries. Proceedings of the EIASM 4th Product Development Management Conference, Fontainebleau, May, pp.205218.

[19] Calabrese, G. (1997). Communication and cooperation in product development: a case study of a European car producer. R\&D Management, Vol. 27, No. 3, pp.239252.

[20] Robertson, D. and Ulrich, K. (1998). Planning for product platforms. Sloan Management Review, Summer, pp.19-31.

[21] McGrath, M.E., (2001). Product Strategy for High Technology Companies: Accelerating Your Business to Web Speed. McGraw-Hill, New York.

[22] Sawhney, M.S., (1998). Leveraged high-variety strategies: From portfolio thinking to platform thinking. Academy of Marketing Science. Journal, Vol. 26, 1998, pp. 54.

[23] Moore, W.L., Louviere, J.J., and Verma, R., (1999). Using conjoint analysis to help design product platforms. Journal of Product Innovation Management, Vol. 16, pp. 27-39. 
[24] Farrell, R.S. and Simpson, T.W., (2001). Improving commonality in custom products using product platforms". Proceedings of ASME 2001 Design Engineering Technical Conferences, Pittsburgh, Pennsylvania.

[25] Sudjianto, A. and Otto, K.N., (2001). Modularization to Support Multiple Brand Platforms, Proceedings of DETC: ASME Design Engineering Technical Conferences, Vol. DETC2001/DTM-21695, Pittsburgh, Pennsylvania.

[26] Kristjansson, A. and Hildre, H.-P., (2004). A Framework for Evaluating Platforms in Product Developing Organizations. Proceedings of 7th Workshop on Product Structuring - Product Platform Development, Gothenburg, Sweden.

[27] Hagedoorn, J. \& Duysters, G., (2002). External sources of innovative capabilities: The preference for strategic alliances or mergers and acquisitions. Journal of Management Studies, 39: 167-188.

[28] Chesbrough, H. (2003). The era of open innovation. Sloan Management Review, 44, 3, 35-41.

[29] Chesbrough, H., Vanhaverbeke, W., West, J., (2006). Open Innovation: Researching a New Paradigm. Oxford University Press, Oxford.

[30] Chesbrough, H., (2003). Open Innovation: The New Imperative for Creating and Profiting from Technology. Harvard Business School Press, Boston, MA.

[31] Roth, V. and Turner, T., (2009). Bezel Swipe: ConflictFree Scrolling and Multiple Selection, Proceedings of the 27th international conference on Human factors in computing systems, Boston, MA.

[32] Apple Inc. iPhone. Available from: http://www.apple.com/iphone/ [cited 14.05.2009].

[33] Rubicon Consulting Inc. The Apple iPhone: Successes sand challenges for the mobile industry. White paper available at: http://rubiconconsulting.com/downloads/whitepapers/R ubicon-iPhone_User_Survey.pdf [cited 14.05.2009].

[34] Sviokla, J., (2008). Apple's iPhone Platform: Your Secret Weapon?. Business Week. available at: http://www.businessweek.com/managing/content/aug20 08/ca20080829_482281.htm?chan=top+news_top+news +index_managing [cited 14.05.2009].

[35] Yoo, Y., Lyytinen, K., Boland, R.J., (2008). Distributed innovation in classes of networks. In: Proceedings of HICSS-41, Waikoloa, BigIsland, Hawaii.

[36] Chesbrough H. (2003). The era of open innovation. Sloan Management Review Summer: 35-41.

[37] Chesbrough, H., (2006). Open innovation: a new paradigm for understanding industrial innovation. In:
Chesbrough, H., Vanhaverbeke,W., West, J. (Eds.), Open innovation: a new paradigm for understanding industrial innovation. Open Innovation: Researching aNew Paradigm. Oxford University Press, Oxford.

[38] Chesbrough, H., Vanhaverbeke, W., West, J., (2006). Open Innovation: Researching a New Paradigm. Oxford University Press, Oxford.

[39] Brown, J.S. and Hagel, J. (2006). Creation Nets: Getting the most from open innovation, in The McKinsey Quarterly

[40] Dittrich, K. and Duysters, G. (2007). Networking as ameans to strategy change: The case of open innovationin mobile telephony, Journal of Product Innovation Management, Vol. 24, No. 6, pp. 510-521.

[41] West, J. \& Gallagher, S. (2006). Challenges of Open Innovation: The Paradox of Firm Investment in Open Source Software. R\&D Management, 36(3): 319-331.

[42] Henkel, J., 2006. Selective revealing in open innovation processes: the case of embedded Linux. Research Policy 35 (7), 953-969.

[43] S. Sarkar, A.I.A. Costa (2008). Dynamics of open innovation in the food industry. Trends in Food Science \& Technology 19 (2008) 574e580

[44] Dodgson, M., Gann, D. and Salter, A. (2006) The role of technology in the shift towards open innovation: The case of Procter\&Gamble. R\&D management 36, 333346.

[45] Halman, Johannes.I.M., Hofer, Adrain P. and van Wuuren, Wim (2003). Platform-Driven Development of Product Families: Linking Theory with Practice. Journal of Product Innovation Management20(2):149162.

[46] Ulrich, K. (1995). The role of product architecture in the manufacturing firm. Research Policy 24(3):419-440 (1995).

[47] Meyer, M.H., Tertzakian, P. and Utterback, J.M., (1997). Metrics for managing research and development in the context of the product family. Management Science 43(1):88-111.

[48] Gorman, T., (2007). Innovation: Create an Idea Culture. Redefine Your Business. Grow Your Profits. Adams Media: F+W Publications, Avon, MA.

[49] Gupta, A.K., P.E. Tesluk, M.S. Taylor. (2007). Innovation at and across multiple levels of analysis. Organization Science 18(6) 885-897.

[50] H. A. Simon, (1996). The Sciences of the Artificial. Cambrdige, MA: MIT Press.

[51] Facebook Developers. Available from: http://developers.facebook.com/ [cited 26.08.2009]. 